\title{
Analisis Tanggung Jawab Pegadaian Syariah Palu Plaza Terhadap Barang Jaminan yang Hilang dan Rusak
}

\author{
Hilal Malarangan ${ }^{1}$ Irfan Irfan ${ }^{2 *}$ Ahmad Haekal2, Rabaniyah Istiqamah ${ }^{4}$ \\ ${ }^{1}$ Jurusaan Ekonomi Syariah, Fakultas Ekonomi dan Bisnis Islam, IAIN Palu \\ 2 Jurusaan Ekonomi Syariah, Fakultas Ekonomi dan Bisnis Islam, IAIN Palu \\ 3 Jurusaan Ekonomi Syariah, Fakultas Ekonomi dan Bisnis Islam, IAIN Palu \\ ${ }^{34} J u r u s a a n$ Ekonomi Syariah, Fakultas Ekonomi dan Bisnis Islam, IAIN Palu
}

\begin{abstract}
ABSTRAK
Tulisan ini membahas tanggung jawab pengadaian syariah terhadap barang jaminan yang hilang dan rusak. Pokok permasalahan adalah bagaimana bentuk tanggung jawab pegadaian syariah apabila barang jaminan yang dititipkan nasabah mengalami kehilangan dan kerusakan. Apakah bentuk tanggung jawab pegadaian syariah sudah sesuai dengan tinjauan ekonomi Islam. Penelitian ini menggunakan metode kualitatif, dengan mengumpulkan data-data melalui, observasi, interview (wawancara), kemudian dari dokumendokumen. Penulis menggunakan teknik analisis data dengan menggunakan teknik pengumpulan data yang digunakan adalah analisis, dan pengecekan keabsahan data. Hasil penelitian ini menunjukan bahwa tanggung jawab yang diberikan oleh pegadaian syariah Palu Plaza telah sesuai dengan ketentuan ekonomi Islam, yaitu melakukan upaya ansitipasi terhadap barang jaminan nasabah dan memberikan ganti rugi kepada nasabah yang mengalami kehilangan atau kecurian barang jaminannya dengan cara mengganti dengan uang atau mengantinya dengan barang yang sama sesuai dengan kesepakatan bersama antara nasabah dan pihak pegadaian. Ansitipasi yang dilakukan oleh pihak pegadaian syariah selain dari tempat penyimpanan yang dijaga dengan ketat. Pegadaian Syariah juga mengansuransikan barang jaminan tersebut.
\end{abstract}

INFORMASI

ARTIKEL

\section{Katakunci:}

Kualitas produk, desain produk, keputusan pembelian 


\section{Pendahuluan}

Adanya pembangunan ekonomi yang berkesinambungan, membuat para pelaku ekonomi baik pemerintah maupun masyarakat, baik perseorangan maupun badan hukum memerlukan dana yang besar. ${ }^{1}$ Tingginya kebutuhan ekonomi untuk memenuhi kebutuhan tidak selamanya bisa dipenuhi individu secara mandiri tetapi memerlukan bantuan orang lain. Kebutuhan akan uang tunai terkadang menjadi kebutuhan yang segera pada waktuwaktu tertentu. Namun demikian, kebutuhan-kebutuhan tersebut ada kalanya tidak diimbangi dengan ketersediaan uang tunai yang dimiliki. Pinjam meminjam uang sering terjadi di masyarakat, sering pula ada pihak-pihak yang terzalimi. Banyak orang yang meminjam uang lantas tidak datang membayar kewajibanya. Hal ini dikarenakan rendahnya nilai kejujuran dan sikap amanah yang saat ini menjadi sesuatu yang mahal, untuk melakukan pinjaman haruslah adanya jaminan untuk memberikan rasa aman bagi pemberi utang, memberikan barang yang mempunyai nilai (harta) dalam pandangan syariat sebagai jaminan utang, yang memungkinkan untuk mengambil seluruh atau sebagian utang dari jasa tersebut.

Untuk memperoleh pinjaman uang, salah satu alternatif aman adalah meminjam uang pada lembaga keuangan misalnya pada bank pemerintah/swasta maupun pada lembaga keuangan non bank, misalnya pegadaian syariah. Pegadaian syariah adalah sebuah badan usaha milik negara

${ }^{1}$ Adrian Sutendi, Hukum Gadai Syariah, (Ed 1, cet, 1, Bandung: PT. Alfabeta,2011), 5.
(BUMN) di Indonesia bergerak di bidang jasa penyaluran kredit kepada masyarakat atas dasar prinsip syariah. Dalam Fatwa Dewan Syariah Nasional (DSN) tentang Rahn (gadai) dijelaskan bahwa pinjaman dengan menggadaikan barang sebagai jaminan utang itu diperbolehkan. ${ }^{2}$

Perusahaan umum pegadaian syariah dalam memberikan kreditnya dilakukan dengan jaminan yang disebut dengan gadai. Dalam pelaksanaan kredit gadai ada dua pihak yang terlibat yaitu pihak yang menerima gadai disebut "pemegang gadai" dan pihak yang menggadaikan disebut "pemberi gadai". Setiap pemberian kredit harus diikuti dengan suatu penjaminan guna pengamanan kredit yang telah diberikan. Dalam hal ini terjadi perjanjian kredit, debitur (orang yang mengambil pinjaman). Menyerahkan benda gadai sebagai jaminan atas pelunasan hutang-hutangnya terhadap kreditur (pemberi pinjaman). Jaminan sangat penting demi menjaga keamanan dan memberikan kepastian hukum bagi kreditur untuk mendapatkan kembali atau mendapatkan kepastian mengenai pengembalian uang pinjaman yang telah diberikan oleh kreditur kepada debitur sesuai dengan waktu yang telah ditetapkan dan kesepakatan bersama.

Pegadaian Syariah Palu Plaza, barang jaminan selain dari emas yaitu hp, eletronik, leptop, kamera, TV, tupperware, motor dan mobil. Gadai tersebut harus diserahkan oleh debitur (orang yang mengambil pinjaman) kepada kreditur (pemberi pinjaman), jadi

${ }^{2}$ Adiwarman A. Karim, Maqashid Bisnis dan Keuangan Islam, ( C,2 Jakarta: Rajawali Pers, 2015), 150. 
barang-barang yang digadaikan berada di bawah kekuasaan pemegang gadai. Hal ini untuk memberikan kepastian bahwa debitur akan melaksanakan kewajibannya sesuai dengan isi perjanjian kredit yang telah dibuat. Sedangkan barang-barang yang menjadi jaminan harus berada di pegadaian sebagai barang jaminan sampai debitur (orang yang mengambil pinjaman), melunasi hutang-hutangnya kepada kreditur (pemberi pinjaman) atau pemegang gadai. Dengan gadai, orang yang mengadakan/pemberian gadai tertutupi kebutuhannya tanpa harus kehilangan harta miliknya. Adapun pemberian utang/pemegang gadai, selain mendapatkan ketenangan dari rasa aman atas haknya, ia juga mendapatkan keuntungan dari bea sewa tempat. Namun barang jaminan utang pihak yang mengadai, pemegang gadai dalam hal ini hanya mempunyai hak kebendaan, tidak boleh memanfaatkan atau menyalahgunakan barang gadai. Selain itu, pemegang gadai juga memiliki tanggung jawab menjaga barang jaminan yang diserahkan dengan baik. Akan tetapi di dalam prakteknya kemungkinan yang dapat timbul, seperti bencana alam atau perampokan yang bisa terjadi kapan saja sehingga dapat mengakibatkan beberapa barang jaminan bisa hilang atau rusak bahkan bisa juga akibat dari peristiwa kelalaian pemegang gadai itu sendiri (dalam hal ini pihak pegadaian syariah) karena tidak menjaganya dengan baik, misalnya barang jaminan yang seharusnya disimpan dalam berangkas penyimpanan barang jaminan tapi pemegang gadai lupa menyimpannya lalu barang jaminan tersebut hilang, maka pemegang gadai sewajarnya bertanggung jawab untuk mengganti kerugiannya, baik mengganti dengan barang yang sama atau mengantinya dengan uang tunai. ${ }^{3}$

Berdasarkan hal tersebut di atas, penulis tertarik untuk membahas dalam bentuk penelitian dengan judul Analisis Tanggung Jawab Pegadaian Syariah Palu Plaza Terhadap Barang Jaminan yang Hilang dan Rusak.

\section{Kerangka Teori}

\subsection{Gadai syariah}

Pegadaian syariah adalah sebuah badan usaha milik negara (BUMN) di Indonesia bergerak di bidang jasa penyaluran kredit kepada masyarakat atas dasar prinsip syariah. Masyarakat yang membutuhkan uang tunai bisa datang meminjam uang dengan barangbarang pribadi sebagai jaminanya dengan manfaat utama yang diperoleh masyarakat (nasabah) dari pegadaian adalah ketersediaan dana dengan prosedur yang relatif lebih sederhana dan dalam waktu yang relatif lebih cepat dibandingkan dengan kredit perbankan. ${ }^{4} \quad$ Berikut Pembahasan mengenai gadai syariah.

\section{a. Pengertian gadai}

Gadai atau Rahn dalam bahasa Arab berarti al-tsubut wa al-darwam (tetap dan kekal). Sebagai ulama memberi

${ }^{3}$ Evi Lutfiaana Dewi, Tanggung Jawab Pegadaian Syariah atas Hilangnya atau Rusaknya Barang Jaminan dalam Perspektif Hukum Islam, (Studi Pada Pegadaian Syariah Cabang Radin Intan),2017,1,http://scholar.google.co.id/schola r. (Online di akses 18 Mei 2018).

${ }^{4}$ Heri Sudarsono. Bank dan Lembaga Keuangan Syariah, (Ed, 4, Yogyakarta: Ekonisia 2013), 172. 
pengertian rahn dengan al-habs (tertahan).Rahn adalah menahan salah satu harta milik seseorang (peminjam) sebagai jaminan atas pinjaman yang telah diterimanya. Barang yang ditahan tersebut memiliki nilai ekonomis. Dengan demikian pihak yang menahan memperoleh jaminan untuk dapat mengambil kembali atas sebagian piutang $^{5}$

Menurut Ahmad Azhar Basyir gadai (rahn) ialah menjadikan sesuatu benda bernilai menurut pandangan syara' sebagai tanggungan hutang dengan adanya benda yang menjadi tanggungan itu seluruh atau sebagaian hutang dapat diterima. ${ }^{6}$

Rahn adalah menahan harta salah satu miliksi peminjam sebagai jaminan atas jaminan yang diterimanya.Secara sederhana dapat dijelaskan bahwa rahn adalah semacam jaminan utang atau gadai. $^{7}$

Menurut UU perdata pasal 1150 gadai adalah hak yang diperbolehkan seseorang yang mempunyai piutang atas suatu barang bergerak, yang diserahkan kepadanya oleh seseorang yang berutang atau oleh seseorang lain atas dirinya, dan yang memberikan kekuasan kepada orang yang berpiutanguntuk mengambil pelunasan dari barang tersebut pada orang yang berpiutang. ${ }^{8}$

${ }^{5}$ Muhammad, Lembaga Ekonomi Syariah, (Jakarta:Graha Ilmu, 2007), 64.

${ }^{6}$ Ahmad Azhari Basyir, Hukum Islam Tentang Riba Utang Piutang Gadai, (Bandung: alMa'arif, 1983), 50.

${ }^{7}$ Muhammad sholahuddin. Lembaga Keuangan dan Ekonomi Islam. (Yogyakarta: OmbakAnggota IKAPI, 2019), 199.

${ }^{8}$ Siagian, sondang P, Manajemen Sumber Daya Manusia, (Jakarta: Bumi Aksara, 2009), 85.
Dari berbagai definisi tersebut diatas, menegenai rahn maka dapat disimpulkan bahwa rahn adalah menjadikan suatu barang yang mempunyai nilai ekonomis untuk diberikan kepada seseorang atau badan usaha sebagai jaminan utang dan jika sudah jatuh tempo orang yang berutang tidak melakukan kewajibannya maka barang tersebut dilelang sesuai syarat.

b. Landasan Gadai syariah

Pada dasarnya semua transaksi memiliki landasan yang menjadi sahnya suatu transaksi, ada pun landasan gadai syariah yang menjadi pijakan penulis dalam penelitian ini adalah Al-qur,an hadis ijma dan Fatwa Dewan Syariah Nasional-Majelis Ulama Indonesia (DSN-MUI) terkait dengan gadai. Fatwa Dewan Syariah NasionalMajelis Ulama Indonesia (DSN-MUI) menjadi landasan gadai syariah karena transaksi dari waktu kewaktu selalu mengalami perkembangan yang tidak menentu sehingga diperlukan adanya Fatwa untuk penyesuaian

\section{a. Jenis Barang Gadai}

Jenis barang gadai yang dapat dijadikan sebagai jaminan adalah semua jenis barang yang bergerak dan tidak bergerak sehingga barang yang dapat digadaikan harus memnuhi syarat sebagai berikut: ${ }^{9}$

1) Merupakan benda yang bernilai menurut hukum syara'.

2) Ada wujudnya ketika perjanjian terjadi.

${ }^{9}$ Kasmir, Bank dan Keuangan Lainnya, (Ed. Revisi C.17.(Jakarta: PT Raja Grafindo Persada, 2016),234-234. 
3) Mungkin diserahkan seketika kepada murtahin.

Selain itu terdapat pula jenis-jenis barang gadai yang digunakan untuk jaminan adalah barang yang dihasilkan dari sumber yang sesuai dengan syari'ah atau keberadaan barang tersebut ditangan nasabah bukan karena hasil praktek riba,gharar, dan maisyir.Barangbarang tersebut antara lain seperti: ${ }^{10}$

a) Barang perhiasan seperti perhiasan yang terbuat dari intan, mutiara, emas, perak, berlian, dan sebagainya.

b) Barang rumah tangga, seperti perlengkapan dapur, perlengkapan makan dan minum, perlengkapan kesehatan, perlengkapan bertanam, dan sebagainnya. Dengan catatan bahwa semua barang-barang yang dijaminkan haruslah dalam kondisi baik dalam arti masih dapat dipergunakan atau bernilai.

c) Barang elektronik seperti, tape recoer, radio, media player, $t v$, komputer, kulkas, dan sebagainya.

d) Kendaraan seperti sepeda onthel, sepeda motor, becak, mobil (termaksud bajai dan bemo).

e) Barang yang dianggap bernilai lainnya. ${ }^{11}$

Keberadaan barang gadai selain karena alasan syari'ah juga dikarenakan alasan keterbatasan tempat penyimpanan barang jaminan mudah rusak dan jenis barang jaminan yang berbahaya seperti barang-barang yang berukuran besar contohnya pesawat terbang, dan kereta api, dan benda yang

${ }^{10}$ Alvien Septian Haerisman, Pegadaian Tinjauan Syariah. PDF File, ( Februari 2016). 20. www.syehknurjati.ac.id.(Online, diakses pada tanggal 10 Februari 2019).

$11 \mathrm{Ibd}, 21$. berbahaya contohnya bahan peledak (bom atau granat), dan senjata api.

Menurut ulama Syafi'iyah bahwa barang yang dapat digadaikan itu berupa barang yang boleh dijual, baik yang bergerak maupun yang tidak bergerak yang terpenting memiliki nilai. Ada beberapa syarat barang jaminan yang harus dimiliki yaitu: 12

(1)Berupa barang yang berwujud nyata didepan mata, karena barang nyata itu dapat diseraterimakan secara langsung.

(2)Barang jaminan itu diseraterimakan langsung saat transaksi gadai terjadi.

(3)Barang jaminan bernilai ekonomis dan dapat diperjualbelikan untuk dijaikan pembayaran marhum.

(4)Barang jaminan itu tidak terkait dengan hak milik orang lain.

(5)Barang jaminan seimbang dengan marhum.

(6)Barang yang digadaikan harus berstatus sebagai piutang bagi pemberi pinjaman.

b. Pemanfaatan barang jaminan

Terkait pemanfaatan barang gadai oleh orang yang mengadaikan, ada dua pendapat pendapat dari kalangan para ulama, mayoritas ulama selain Syafi'iyah berpendapat bahwa orang yang mengadaikan tidak boleh memanfaatkan barang gadai. ${ }^{13}$ Sementara kalangan Syafi'yah memper bolehkan pihak yang mengadaikan memanfaatkan barang gadaian selama tidak menimbulkan perselisihan dengan pihak yang menerima gadai.

${ }^{12}$ Adrean Sutedi, Hukum Gadai Syariah, (Bandung: Alfabeta, 2011), 107-108.

13Imam Mustofa, Fiqih Mu'amalah Kontemporer (Ed, 1, Cet 1, Jakarta: Rajawali Pers, 2016), 190.

e-ISSN: $2686-6633$ 
Kalangan Hanafiyah berperdapat bahwa pihak yang mengadaikan tidak boleh memanfaatkan barang yang telah digadaikan, apa pun jenis dan bentuk barang gadai tersebut, baik kendaraan, tempat tinggal dan lainnya, kecuali penerima gadai mengizinkannya. Hal ini juga berlaku kepada pihak penerima gadai, dia tidak diperbolehkan memanfaatkan barang gadai atau jaminan kecuali diizinkan oleh pihak penerima gadai.Kalangan Hanbali berpendapat senada dengan kalangan Hanafiyah. Mereka tidak memperbolehkan bagi pihak yang mengadaikan untuk memanfatkan barang gadai.karena barang pegadaian syariah pada dasarnya sedang dalam penahanan di tengah penerima gadai, maka pemilik barang gadai atau pihak yang mengadaikan tidak boleh memanfaatkannya kecuali seizin pihak penerima gadai.

Kalangan Malikiyah lebih ekstrim, bagi pihak yang mengadaikan tidak boleh memanfaatkan barang gadai.meskipun puhak penerima gadai mengizinkannya. Izin yang diberika pihak penerima gadai itu membatalkan gadai bagi Malikiyah memang manfaat barang gadai menjadi hak bagi pemilik barang namun iya harus menyerahkan kepada penerima gadai. ${ }^{14}$

c. Pemeliharaan barang gadai

Ada perbedaan pendapat para ulama dalam hal pemeliharaan barang gadai ulama Syafi'ah dan hambaliah berpendapat biaya pemeliharaan barang gadai menjadi tanggung jawab pemberi gadai karena barang tersebut

14Imam Mustofa, Fiqih Mu'amalah Kontenporer (Ed, 1, Cet 1, Jakarta: Rajawali Pers, 2016), 199. merupakan miliknya dan akan kembali kepadanya.Sedangkan para ulama Hanafiyah berpendapat bahwa biaya pemeliharaan barang gadai menjadi tanggungan penerima gadai yang mana dalam posisinya sebagai penerima amanat.

Berdasarkan pendapat tersebut di atas, maka dapat disimpulkan bahwa biaya pemeliharaan barang gadai adalah hak rahin dalam kedudukannya sebagai pemilik yang sah.Akan tetapi jika harta atau barang jaminan tersebut menjadi kekuasaan murtahin dan diizinkan oleh rahin, maka biaya pemeliharaan jatuh pada murtahin. ${ }^{15}$ Sedangkan untuk mengganti biaya tersebut nantinya, apabila murtahin mendapat izin dari rahin maka murtahin dapat memungut hasil marhunsesuai dan senilai dengan yang telah ia keluarkan. Tetapi apabila rahin tidak mengizinkannya maka biaya memelihara menjadi hutang rahin kepada murtahin.

Resiko atas kerusakan menurut para ulama Syafi'iah dan Hambaliah berpendapat bahwa murtahin tidak bertanggung jawab atas rusaknya barang gadai jika tidak disengaja.Sedangkan ulama Hanafiyah berpendapat bahwa hal tersebut menjadi tanggungan murtahin sebesar harga minimum, dihitung mulai waktu diserahkannya barang gadai kepada murtahin sampai barang tersebut rusak.Pembayaran atau pelunasan hutang gadai apabila sudah sampai jatuh tempo dan rahin belum membayarkan kembali utangnya, maka murtahin boleh memaksa rahin untuk menjual barangnya. Kemudaian

${ }^{15}$ Muhammad Shalikul Hadi, Pegadaian Syariah, (Jakarta: Salembah Diniyah, 2003), 17.

e-ISSN: 2686-6633 
hasilnya digunakan untuk menebus utang tersebut sedangkan jika terdapat sisa atas penjualan barang tersebut, maka akan dikembalikan kepada rahin.

Prosedur pelelangan gadi jika ada persyaratan akan menjual barang gadai pada saat jatuh tempo, maka ini diperbolehkan dengan ketentuan yaitu, murtahin harus mengetahui terlebih dahulu keadaan rahin, dapat memperpanjang tenggang waktu pembayaran, kalau keadaan mendesak murtahin boleh memindahkan barang gadai kepada murtahin lain dengan izin rahin dan apabilah ketentuan tidak terpenuhi, maka murtahinmaka murtahin boleh menjual barang gadai dan kelebihan utangnya dikembalikan kepada rahin. ${ }^{16}$

\section{d. Nilai-nilai dasar ekonomi Islam}

Moral Islam sebagai pilar ekonomi Islam perlu dijabarkan lebih lanjut menjadi nilai-nilai yang lebih terinci sehingga pada akhirnya dapat menjadi rumusan penuntun perilaku para pelaku ekonomi ${ }^{17}$. Nilai-nilai merupakan sisi normatif dari ekonomi Islam yang berfungsi menjamin kualitas perilaku ekonomi, nilai dasar yang menjadi pembeda ekonomi Islam dengan yang lainnya yaitu:

1) Adl

Keadilan (adl) merupakan nilai paling asasi dalam ajaran Islam. Menegakkan keadilan dan memberantas kezaliman adalah tujuan utama dari risalah para Rasul-Nya keadilan sering kali diletakkan sederajat dengan kebijakan dan ketakwaan, maka bisa

$16 \mathrm{Ibd}, 85$.

17Pusat Pengkajian dan Pengembangan Ekonomi Islam, Ekonomi Islam,(Cet , 4, Jakarta: PT Raja Grafindo Persada, 2012), 58. bisa diturunkan berbagai nilai turunan yang berasal darinya yaitu, Persamaan kompensasi, merupakan pengertian adil yang paling umum yaitu bahwa seseorang harus memberikan kompensasi yang sepadan kepada pihak lain sesuai dengan pengorbanan yang telah dilakukan.Persamaan hukum, yaitu memberikan makna bahwa setia orang harus diperlakukan sama di depan hukum.Moderat, yaitu sebagai posisi tengah-tengah.Nilai adil disini dianggap telah diterapkan seseorang jika orang yang bersangkutan mampu memposisikan dirinya dalam posisi di tengah artinya tidak mengambil keputusan yang terlalu mempererat ataupun keputusan yang terlalu memperingan.

Kenyataan ini menunjukkan bahwa, keadilan mmpunyai makna yang dalam dan urgen dalam Islam serta menyangkut seluruh aspek kehidupan.Karena itu, keadilan merupakan dasar, sekaligus tujuan semua tindakan manusia dalam kehidupan. Salah satu sumbagan terbesar islam kepada umat manusia adalah prinsip keadilan dan pelaksanaannya dalam setiap aspek kehidupan. Islam mendidik umat manusia bertanggung jawab kepada keluarga, fakir mskin, Negara, bahkan seluruh makhluk di muka bumi. ${ }^{18}$

2) Khilafah

Nilai khilafah secara umum berarti tanggun jawab sebagai pengganti atau utusan Allah di alam semesta. Khilafah bermakna tanggung jawab berperilaku ekonomi dengan cara yang

18Rozalinda, Ekonomi Islam Teori dan Aplikasinya pada Aktivitas Ekonomi, (Ed, 1, Cet, 3 Jakarta: Rajawali, 2016), 20-21.

e-ISSN: $2686-6633$ 
benar, tanggung jawab untuk mmewujudkan mashlahah maksimum dan tanggung jawab perbaikan kesejahteraan setiap individu. ${ }^{19}$

3) Takaful

Konsep takaful dijabarkan sebagai jaminan terhadap pemilikan dan pengelolaan sumber daya oleh individu, jaminan setiap individu untuk menikmati hasil pembagunan atau output, serta jaminan setiap individu untuk membangun keluarga sakinah dan jaminan untuk amar ma'ruf nahi munkar. ${ }^{20}$

2.2 Tanggung Jawab atas Kerusakan dan Hilangnya barang Jaminan

Menurut Syafi'iyah bila barang gadai atau mahrun hilang dibawah pengawasan murtahin, maka al-murtahin tidak wajib menggantinya. ${ }^{21}$ Kecuali bila rusak atau hilangnya itu karena kelalaian murtahinatau karena disiasiakan umpamanya, murtahin bermain-main api lalu barang gadai itu terbakar, atau gudangnya tidak dikunci lalu barang gadai tersebut dicuri orang. Kongkretnya murtahin diwajibkan memelihara mahrum secara layak dan wajar. Sebab bila tidak demikian, ketika ada cacat atau kerusakan apalagi hilang menjadi tanggung jawaban murtahin. Menurut Hanafi dan Ahmad Azhari Basyir, menyatakan bahwa murtahin yang memegang mahrun, menanggung resiko kerusakan atau kehilangan marhun, bila mahrumitu rusak atau hilang, baik karena kelalaian maupun tidak.

19Pusat Pengkajian dan Pengembangan

Ekonomi Islam, Ekonomi Islam, 62.

${ }^{20} \mathrm{Ibd}, 63$.

${ }^{21}$ Abdul Rahman Ghazali, Figh Muamala,

( Ed.1, C. 1, (Jakarta: Kencana, 2010), 270.
Perbedaan dua pendapat tersebut ialah jika menurut Hanafi murtahinharus menanggung resiko kerusakan atau kehilangan al-mahrun dipegangnya, baikmahrun itu hilang karena disiasiakan atau atau dengan sendirinya, sedangkan menurut Syafi'iyah murtahin menanggung resiko kehilangan atau kerusakan mahrum bila mahrum itu rusak atau hilang karena tidak diurus atau disia-siakan oleh murtahin. ${ }^{22}$

Jika barang yang digadaikan rusak ditangan murtahin (penerima gadai) bukan karena teledor atau menyianyiakannya atau jika barang itu harganya lebih mahal dari utangnya atau harganya sama dengan utangnya, maka habislah utangnya dan murtahin tidak perlu menambah sisa harga barang itu. Jika barang itu lebih murah dari utangnya, maka besar utang yang seharga dengan barang itu habis, kemudian sisa utangnya harus dibayarkan oleh rahin(pengadai) kepada murtahin(penerima gadai). ${ }^{23}$ kalau barang itu rusak atau hilang di tangan orang yang jujur, maka ditanggung sendiri oleh yang mengadakan. Kalau hilang ketika berada pada penerima gadai, maka dia sendiri yang menanggung. Apabila barang rusak dengan sendirinya, bukan karena perbuatan penerima gadai, maka hal ini tidak bisa melepaskan utang. Artinya utang yang telah dipinjamkan kepada orang yang mengadaikan harus dibayar juga.

\subsection{Jaminan}

Istilah "jaminan" berasal dari kata "jamin" yang berarti tanggung sehingga

${ }^{22} \mathrm{Ibd}, 271$.

23Idri, Hadis Ekonomi dalam Perspektif Hadis Nabi, (Jakarta: Kencana, 2015) , 215. 
istilah "jamin" dapat diartikan tanggungan. Jaminan adalah suatu yang diberikan kepada kreditur untuk menimbulkan keyakinan bahwa debiturakan memenuhi kewjiban yang dapat dinilai dengan uang yang timbul dari suatu perikatan. ${ }^{24}$

Dewan penasehat syariah bank negara malaysia mendefinisika jaminansebagai "kontrak terjamin atas suatu aset, manfaat, dan jasa tertentu, yang disediakan oleh peminjam kepada pihak yang terlibat". Umumnya, Kafalah berarti jaminan atau mengambil tanggung jawab membayarkan suatu utang atau atas kehadiran seseorang di pegadaian. ${ }^{25}$

Dari uraian tersebut diatas, dapat disimpulkan bahwa jaminan merupakan barang yang disediakan peminjam untuk diberikan kepada yang memberi jaminan, jika pinjaman gagal dibayarkan maka pihak pemberi pinjaman dapat memiliki barang jaminan tersebut. Dalam kredit jaminan sering menjadi faktor yang penting untuk meningkatkan nilai kredit perseorangan ataupun perusahan, bahkan dalam perjanjian kredit gadai jaminan merupakan satu-satunya faktor yang dinilai dalam menentukan besarnya pinjan.

Jaminan dalam pembiyaan memiliki dua fungsi yaitu:

1) Untuk pembayaran hutang seandainya tidak melaksanakan kewajiban sebagaimana mestinya yang dibebankan oleh kontrak

\footnotetext{
${ }^{24}$ Martono, Hukum Perdata Internasional dan Nasional, (Jakarta: Rajawali Pers, 2013), 244.

${ }^{25}$ Internasional Shari'ah Research Academy for Islamic Finance (ISRA). Sistem Keuangan Islam: Prinsip dan Oprasional/ISRA (Ed.1-Cet. 1, (Jakarta: Rajawali pers, 2015), 304.
}

terhadap pihak-pihak tertentu seperti yang disebutkan dalam kontrak yang bersangkutan atas pihak ketiga yaitu dengan jalan menguangkan atau menjual jaminan tersebut.

2) Sebagai indikator penentu jumlah pembiyayan yang akan diberikan kepada pihak debitur. Pemberian jumlah pembiayaan tidak boleh melebihi nilai harta yang dijaminkan. ${ }^{26}$

Dari uraian di atas, dapat disimpulkan bahwa fungsi jaminan adalah untuk menyakinkan kreditur bahwa debitur mempunyai kemampuan untuk melunasi kredit yang diberikan kepadanya sesuai yang diperjanjikan.Jaminan dapat membantu memperoleh pembiayan bagi pihak ketiga dan tidak melemahkan potensi pihak ketiga untuk menerima pembiayaan guna meneruskan usahanya, dan memberikan kepastian kepada pihakkreditur untuk mengeluarkan pembiayaan dan mudah digunakan apabila terjadi hal yang tidak diinginkan.

c Barang Jaminan

Jenis barang yang dapat diterima sebagai barang jaminan pada prinsipnya adalah barang bergerak dan barang tidak bergerak, yaitu:

1) Barang-barang perhiasan, yaitu semua perhiasan yang dibuat dari emas, perhiasan perak, platina, baik yang berhiasan intan, mutiara, batu maupun tidak.

2) Barang-barang elektronik: TV, kulkas, radio, tape recorder, dan lain-lain.

${ }^{26}$ Faturrahman Djamil, Penyelesaian Pembiayaan Bermasalah di Bank, (Jakarta: Sinar Grafika, 2000), 281. 
3) Kendaraan: sepeda, sepeda motor, dan mobil.

4) Barang-barang rumah tangga: barang-barang pecah belah.

5) Mesin: mesin jahit dan mesin motor kapal.

6) Testil: kain batik dan permadani.

7) Barang-barang lain yang dianggap bernilai. ${ }^{27}$

Dari uraian tersebut di atas, dapat disimpulkan bahwa barang jaminan yang dijadikan jaminan adalah benda yang bergerak dan benda tidak bergerak atau benda yang memiliki nilai. Namun untuk barang jaminan di pegadaian syariah sebagai pelunasan pinjaman hanya meliputi, barang yang berharga atau mempunyai nilai ekonomis serta dapat disimpan/bertahan lama.

\section{Metode Penelitian}

Metode merupakan suatu prosedur tata cara megetahui sesuatu yang mempunyai langka sistematis. ${ }^{28}$ Dalam penulisan karya ilmiah, penulis menggunakan metode pendekatan kualitatif dan jenis penelitian deskriptif. Metode kualitatif dapat digunakan untuk mengungkap dan memahami sesuatu di balik fenomena yang sedikit pun belum diketahui. Metode ini dapat juga digunakan untuk menambah wawasan tentang sesuatu yang belum diketahui. ${ }^{29}$ Peneliti dalam penelitian kualitatif ini akan mencoba mengerti

${ }^{27}$ Martono. Bank dan Lembaga Keuangan Lain, (Yogyakarta: Ekonisa, 2002), 175.

28 Muhammad, Metodologi Penelitian Ekonomi Islam Pendekatan kualitatif, (Jakarta: Rajawali PT. Raja grafindo Persada, 2008), 12.

29 Ansel Struss dan Julet Corbin, DasarDasar Penelitian Kualitatif, (Yogyakarta : Pustaka pelajar, 2007), 5 . makna suatu kejadian atau peristiwa dengan mencoba berinteraksi dengan orang-orang dalam situasi/fenomena tersebut.

Penggunakan metode kualitatif dalam penelitian ini dengan beberapa pertimbangan. Pertama, menyesuaikan metode kualitatif lebih mudah apabila berhadapan dengan kenyataan ganda. Kedua, dapat menyajikan secara langsung hakikat hubungan antara peneliti dengan informan ${ }^{30}$. Ketiga, Metode ini lebih peka dan lebih menyesuaikan diri dengan banyak penajaman pengarah bersama dan terhadap pola-pola nilai yang dihadapi. ${ }^{31}$

Penelitian ini dilaksanakan di Pegadaian Syariah Kota Palu yang berlokasi di jalan Danau Poso Blok A NO. 11 Palu Barat. Lokasi tersebut dipilih karena identitas dari penelitian untuk mengumpulkan data yang sesuai dengan kebutuhan dalam penyusunan skripsi ini. Kemudian semakin banyaknya masyarakat yang berminat untuk menggadaikan barang dalam mengatasi biaya yang membuat orang makin terdesak dengan kebutuhan hidup yang dialami, sehingga masyarakat beralih kepada pegadaian untuk mendapatkan bantuan dengan menggadaikan barangnya yang berharga.

Data dikumpul dengan menggunakan teknik observasi, wawancara mendalam dan kajian dari

30 Nurdin, N. (2017a). Research in Online Space: The Use of Social Media for Research Setting Jurnal Sistem Informasi (Journal of Information System), 13(1), 67-77.

31Ibid., 5.

e-ISSN: 2686-6633 
berbabagi dokumen tertulis ${ }^{32}$. Sedangkan analisa data dilakukan dengan menggunakan teknik reduksi dan verifikasi dengan berbagai sumber data $^{33}$. Data yang sudah direduksi kemudian dianalisis dengan mengaku pada konsep teori yang digunakan dalam penelitian ini.

\section{Hasil dan Pembahasan}

\subsection{Tanggung Jawab Pegadaian Syariah} terhadap Barang Jaminan yang Hilang dan Rusak.

Untuk

meminimalisir

kemungkinan terjadinya barang jaminan yang hilang dan rusak, ada beberapa upaya ansitipasi yang dilakukan pegadaian syariah Palu Plaza yakni:

a. Adanya dasar hukum yang melandasi oprasional Pegadaian Syariah Palu Plaza dalam hal tanggung jawab kreditur atas hilangnya barang gadai

Berkaitan dengan dasar hukum yang melandasi oprasional Pegadaian Syariah Palu Plaza, dapat dilihat dalam kitab Undang-Undang Hukum Perdata (KUHP) pasal 1150, 1154, 1156, 1157, 1244, 1245 dan 1338. 34

32 Nurdin, N. (2017b). To Research Online or Not to Research Online: Using Internet-Based Research in Islamic Studies Context. Indonesian Journal of Islam and Muslim Societies, 7(1), 31-54.

33 Nurdin, N. (2016). The Roles of Information Technology in Islamic Bank Knowledge Management: A study of Two Syariah Banks in Palu. Hunafa: Jurnal Studia Islamika, 13(2),

181-217. https://doi.org/https://doi.org/10.24239/jsi.v1 3i2.444.181-217

34 Amalia Yustika Febriani, I Made Budi Ariska, "Tanggung Jawab Kreditor atas Hilangnya Barang Gadai" (Jurnal diberikan oleh Riski
Pasal 1150 kitab Undang-undang Hukum Perdata (KUH Perdata) gadai didefenisikan sebagai suatu hak yang diperoleh kreditor atas suatu kebendaan bergerak, yang diserahkan kepadanya oleh seseorang debitur atau oleh orang lain atas debitur, dan yang memberikan kekuasaan kepada kreditur untuk mengambil pelunasan dari barang tersebut secara didahulukan dari para kreditur lainnya. Penerima gadai baik orang atau badan hukum yang menerima jaminan untuk pinjaman uang yang diserahkan oleh debitur.

Di Indonesia, badan hukum yang ditunjuk untuk mengelola lembaga gadai adalah perusahan pegadaian. Ada pun tujuan Pegadaian Syariah Palu Plaza umumnya yaitu menghindarkan masyarakat dari gadai gelap, praktek riba dan pinjaman tidak wajar lainnya (Pasal 7 ayat (2) Peraturan Pemerintah Nomor 103 Tahun 2000 tentang Perusahaan Umum (Perum) Pegadaian).

Dari adanya perjanjian gadai perjanjian gadai yang didasarkan pada penyerahan benda bergerak kepada penerima gadai (kreditor), maka berdasarkan Pasal 1154 KUH Perdata kreditur mempunyai kewajiban tidak diperkenankan mengalihkan barang yang digadaikan menjadi miliknya walaupun pemberi gadai wanperstasi dan mempunyai kewajiban untuk menjaga barang yang digadaikan.

Berdasarkan Pasal 1156 KUH Perdata, penerima gadai memberitahukan kepada pemberi gadai (debitur) tentang pemindahan barang gadai. Dengan adanya kewajiban kreditur tersebut, maka kreditur wajib

Oktavian dikirim melalui (Whatsapp) 12 juni 2019). 
bertanggungjawab terhadap benda gadai yang hilang. Selain terdapat dalam Pasal 1157 ayat (1) KUH Perdata, terdapat juga pada angka (4) isi perjanjian kreditur dengan jaminan barang bergerak yang telah di lakukan pegadaian yang menyatakan: "Barang jaminan sebagaimana diuraikan di halaman depan, bila di kemudian hari barang jaminan hilang dan rusak akan dig anti sebesar $125 \%$ dari nilai taksiran, setelah dikurangi uang pinjaman dan sewa modal. Pegadaian tidak bertanggung jawab atas kerugian apabila terjadi force majeure ( kejadian yang terjadi di luar kemampuan manusia) antara lain bencana alam, huru-hara, dan perang". 35

Lain halnya apabila kreditur dapat membuktikan bahwa benda gadai tersebut hilang atau dicuri bukan karena kelalaianya atau disebabkan karena terjadi bencana alam, huru-hara dan perang. Hal tersebut terdapat dalam Pasal 1244 KUH Perdata dan pasal 1245 KUH Perdata. Pasal 1244 KUH Perdata menyatakan: "Jika ada alasan untuk itu, si berutang harus dihukum mengganti biaya rugi apabila ia tak dapat membuktikan, bahwa hal tidak atau tidak pada waktu yang tepat dilaksanakannya perikatan itu, disebabkan suatu hal yang terduga, ataupun tak dpat dipertanggungjwabkan padanya, kesemuanya itu pun jika itikad buruk tidaklah ada pada pihaknya".

Selanjutnya Pasal 1245 KUH perdata menyatakan: "Tidaklah biaya rugi harus digantinya, apabila lantaran

35 Amalia Yustika Febriani, I Made Budi Ariska, "Tanggung Jawab Kreditor atas Hilangnya Barang Gadai" , 4. keadaan memaksa atau lantaran sesuatu kejadian tak disengaja si berutang berbuat sesuatu yang diwajibkan, atau lantaran hal-hal yang sama telah melakukan yang terlarang."

Tetapi bila dilihat dari Pasal 1244 KUH Perdata dan Pasal 1245 KUH Perdata hanya mengatur apabila debitur yang mengalami force majeure (kejadian yang terjadi diluar kemampuan manusia). Maka perjanjian kredit yang telah dibakukan tersebut sudah mengatur bahwa kreditur tidak bertanggung jawab dalam kerugian yang disebabkan karena force majeure (kejadian yang terjdi diluar kemampuan manusia). Dapat dilihat dalam Pasal 1338 KUH perdata bahwa: "semua perjanjian yang dibuat secara sah berlaku sebagai undang-undang bagi mereka yang membuatnya". Setiap subjek hukum bebas aturan dimana aturan tersebut belum ada dalam KUH Perdata. ${ }^{36}$

Berdasarkan uraian tersebut di atas, penulis dapat menyimpulkan bahwa tujuan Pegadaian Syariah Palu Plaza umumnya yaitu menghindarkan masyarakat dari gadai gelap, prakterk riba dan pinjaman tidak wajar, dan tidak diperkenankan mengalihkan barang jaminan jika terjadi kecurian atau kerusakan akibat bencana alam. kreditur tidak bertanggung jawab dalam kerugian yang disebabkan karena force majeure (kejadian yang terjadi diluar kemampuan manusia), seperti bencana alam huru-hara dan perang.

Fasilitas merupakan salah satu faktor penilaian dalam melihat aspek

${ }^{36}$ Amalia Yustika Febriani, I Made Budi Ariska, "Tanggung Jawab Kreditor atas Hilangnya Barang Gadai", 5. 
pelayanan yang berlangsung saat transaksi. Karena setiap instansi wajib memiliki sarana dan prasarana yang memadai dalam menunjukan proses pelayanan ketika ada nasabah yang sedang melakukan transaksi tersebut. Sarana dan prasarana memiliki peran yang sangat penting dalam mendukung keamanan barang jaminan nasabah yang diserahkan kepada pihak Pegadaian, sarana dan prasarana bertujuan untuk menjaga keamanan agar meminimalisir terjadinya kecurian atau kerusakan barang jaminan nasabah.

Berdasarkan hasil wawancara dengan salah satu pegawai syariah Palu Plaza, yaitu Rizki Oktavian menjelaskan bahwa sarana dan prasaranan yang dimiliki pegadaian syariah Palu Plaza dalam hal keamanan barang jaminan nasabah yaitu:

1) Brangkas

Berangkas yaitu tempat penyimpanan dengan kapasitas dan fitur masing-masing dan merupakan salah satu lemari penyimpanan yang paling aman yang terbuat dari besi dan baja yang sistem pengunciannya menggunakan kunci kombinasi atau digital lock. Barangkas dalam pegadaian syariah Palu Plaza memiliki fungsi sebagai tempat penyimpanan barangbarang berharga dengan sistem keamanan dan ketahanan yang tinggi untuk melindungi barang-barang berharga anda dari bahaya pencurian ataupun kebakaran.

2) CCTV dan Alaram

CCTV dan Alarm yaitu merupakan sistem keamanan yang memiliki peranan yang sangat penting didalam menjaga sistem keamanan. Hal ini sesuai dengan ungkapan Rizki Oktavian bahwa:
Pegadaian Syariah Palu Plaza di lengkapi dengan peralatanperalatan keamanan CCTVnya lengkap semua, alarmnya lengkap. Alarmnya online sudah jadi kalau bunyi disini ketahuan di kantor cabang ketahuan juga di kantor pusat jadi seperti itu. ${ }^{37}$

Berdasarkan pernyataan tersebut di atas, CCTV memiliki fungsi dan tujuan untuk mencegah pelaku kriminal menurunkan niatnya atau merasa takut ketika melihat terpasangnya kamera CCTV, memantau dengan mudah untuk membantu dalam memonitoring atau memgawasi situasi serta kegiatan yang terjadi dilokasi yang terpasang kamera CCTV.

Peningkatan kinerja karyawan dengan adanya CCTV maka akan meningkatkan kinerja karyawan secara signifikan dalam hal ini CCTV yang dipasang ditiap-tiap sisi kantor untuk meninjau pekerjaan yang dilakukan setiap karyawan, penyelidikan dengan sistem CCTV akan lebih mudah untuk menunjang penyelidikan terhadap tindakan kejahatan yang terjadi dan bukti yang terekam CCTV dapat dijadikan bukti apabilah terjadi aksi kejahatan.

Pasalnya, dengan CCTV tidak kejahatan akan tersimpan dengan rapi sehingga dapat menjadi bukti untuk pelaporan kepada pihak yang berwajib. Dengan begitu pihak pegdaian juga bisa langsung mengetahui jika ada orangorang yang tidak dikenal memasuki daerah yang sudah terpasang CCTV.

37 Rizki Oktavian, Pengelola Unit Pegadaian Syariah Pasar Inpres, "Wawancara" Tempat Unit Pegadaian Syariah Pasar Inpres, Senin 27 Mei, detik 17:40. 
Sedangkan alaram berfungsi memberitahukan apabilah terjadi bahaya dan kerusakan ataupun kejadian yang tidak diharapkan pada jaringan melalui sinyal sehingga memberikan peringatan secara jelas agar dapat diantisipasi. Sistem alaram di pegadaian syariah Palu Plaza saling terhubung antara cabang dan unit-unitnya yang berada di daerah berbeda. Apabila terjadi bahaya atau kecurian di kantor unit makan secara otomatis alaram tersebut akan memberitahukan kejadian kecurian dan bahaya tersebut ke kantor cabang sehingga kejadian tersebut segerah ditangani. Peralatan keamanan seperti CCTV dan alaram di pegadaian syariah Palu Plaza secara otomatis online selama 24 jam.

3) Security (satpam) Security/satpam adalah melindungi dan mengayomi lingkungan tempat kerja dari setiap gangguan keamanan, serta menegakkan peraturan dan tata tertib yang berlaku dilingkungan kerja, hal ini sesuai dengan ungkapan Rizki Oktavian bahwa: "Sudah jelas to security menjaga keamanan di dalam kantor to". ${ }^{38}$

Bukan hanya itu peranan satpam dalam pelaksanaan tugas dan kewajibanya dan dilihat dari kebutuhan perusahan yaitu, penjagaan setiap keamanan memiliki fungsi dan tugas yang sama secara umum menjaga dan mengamankan semua aset, karyawan, atasan dan keamanan kerja di lingkungan kerja atau tempat-tempat

38 Rizki Oktavian, Pengelola Unit Pegadaian Syariah Pasar Inpres, "Wawancara" Tempat Unit Pegadaian Syariah Pasar Inpres, Senin 27 Mei, detik 17:32 tertentu sesuai dengan yang diatur oleh perusahan atau atasan.

Melakukan pengawalan pada atasan atau aset perusahan yang dibawa atau dipindahkan atau diambil dari tempat lain yang diperlukan perusahaan atau yang dikeluarkan oleh perusahan. Kemudian satpan melakukan patrol yang diwajibkan kepada setiap petugas keamanan yang ditempatkan di setiap kantor pegadaian dan dapat melakukan pencegahan apabila dalam melakukan patroli mendapati hal-hal yang mencurigakan atau janggal dan melakukan pencekalan apabila terdapat hal-hal yang merupakan suatu pelanggaran di dalam sistem pengamana. Stpan juga memiliki peranan sebagai penyelidikan. Agar dapat mengantisipasi sebelumnya untuk tidak terjadi hal-hal yang merugikan. Satpam juga melakukan pelaporan kepada atasan dan harus melaporkan segala sesuatu yang dianggap perlu dilaporkan. Kemudian mengamankan keamanan yang mempunyai hak untuk mengamankan. Kemudian tugas dari seorang satpan adalah senyum, satpam dan salam.

4) Kerangkeng

Kerangkeng yaitu kurungan berpagar besi atau suatu tempat bertirai besi di Pegadaian Syariah Palu Plaza. Salah satu fungsi dari karangkeng adalah pagar pemisah antara ruang antri nasabah dan pegawai yang melayani nasabah.

b. Pengelolaan barang jaminan

Sebelum pihak Pegadaian Syariah Palu Plaza menerima barang jaminan dari nasabah, Pihak pegadaian melakukan pengecekan terhadap barang jaminan yang dimiliki calon nasabah untuk diterima sebagai barang jaminan. 
Setelah barang jaminan tersebut dicek sekaligus ditaksir oleh penaksir, maka pihak pegadaian menerima barang tersebut sebagai barang jaminan.

Dalam hal pengelolaan barang jaminan berupa kendaraan, baik roda dua (motor), maupun roda empat (mobil), maupun alat-alat eletronik seperti leptop, perawatan yang dilakukan Pegadaian Syariah Palu Plaza adalah sebagaimana yang diungkapakan oleh Rizki Oktavian sebagai berikut:

Untuk ansitipasinya sih untuk eletronik memang ada SOP Khusus untuk kendaran kaya kendaraan motor memang harus dipanaskan secara berkala $1 \mathrm{~m}$ inggu 2 kali dikasi panas, itu motor untuk leptop itu leptop paling para apa lagi laptop betrei tanam biasa kita kasi hidup tapi tidak dipakai dicek dia punya sistem itu 1 bulan 2 kali. ${ }^{39}$

Berdasarkan pernyatan tersebut di atas, dapat diketahui bahwa pengelolaan barang jaminan yang ada di Pegadaian Syariah Palu Plaza dilakukan dengan pengecekan secara berkala baik itu barang jaminan eletronik maupun kendaraan. Pengecekan roda dua seperti, motor yang harus dirawat dengan melakukan pengecekan mesin dua kali dalam seminggu. Begitu pun dengan kendaran roda empat (mobil). Pengecekan kendaraan tersebut dilakukan dua kali dalam seminggu. Khusus alat eletronik seperti laptop, perawatan yang dilakukan pegadaian syariah Palu Plaza adalah melakukan

39 Rizki Oktavian, Pengelola Unit Pegadaian Syariah Pasar Inpres, "Wawancara" Tempat Unit Pegadaian Syariah Pasar Inpres, Senin 27 Mei, detik 15:00. pengecekan satu bulan sekali untuk memastikan barang jaminan nasabah dalam kondisi baik dan untuk mengantisipasi kerusakan dari barang tersebut.

c. Mengasuransikan barang jaminan

Apabila terdapat kemungkinan buruk yang akan terjadi terhadap barang jaminan nasabah seperti mengalami kerusakan atau hilang, baik disengaja ataupun tidak disengaja, misalnya akibat terjadinya bencana alam, seperti banjir likuifaksi dan gempa yang menyebabkan barang jaminan nasabah hilang dan rusak, maka pihak Pegadaian Syariah mengansuransikan barang jaminan tersebut.

Dalam hal ini Pegadaian Syariah Palu Plaza melakukan kerja sama dengan perusahaan asuransi untuk mengasuransikan barang jaminan yang diterima Pegadaian Syariah Palu Plaza, hal ini sesuai dengan ungkapan Rezki Oktavian: "semua barang yang masuk disini itu diasuransikan jadi semua ada asuransinya". ${ }^{0}$ Hal ini merupakan bentuk tanggung jawab pegadaian syariah Palu Plaza terhadap barang jaminan yang hilang dan rusak.

Untuk melakukan ganti rugi. Baik hilang dan rusak disebabkan karena kehilangan dan rusak misalnya kecuria atau bencana alam maupun hilang dan rusak akibat kelalaian pegawai itu sendiri. Rizki oktavian menyatakan bahwa:

Kalau misalnya hilang karena kelalaian rusak karena kelalaian Karena dia lalai menyimpan harusnya kan diisi di berangkas

40 Rizki Oktavian, Pengelola Unit Pegadaian Syariah Pasar Inpres, "Wawancara" Tempat Unit Pegadaian Syariah Pasar Inpres, Senin 27 Mei, detik 13:53.

e-ISSN: $2686-6633$ 
ternyata tatinggal di luar terus di curi di tanggung asuransi sesaui sopnya pegadaian penyimpanan barang saja kalau barang eletronik disimpanya dalam gudang ternyata dicuri itu ditanggung asuransi. ${ }^{41}$

Berdasarkan pernyataan tersebut di atas, untuk mngurangi resiko kecurian atau kelalaian yang menyebabkan barang jaminan nasabah hiang dan rusak maka, pihak pegadaian harus lebih berhati-hati dalam menjaga barang jaminan tersebut. Agar barang jaminan nasabah aman dan terjaga.

\subsection{Melakukan penggantian atas hilang atau} rusaknya barang jaminan nasabah

Apabilah barang jaminan nasabah mengalami kerusakan atau hilang, baik disengaja ataupun tidak disengaja, misalnya akibat terjadinya kecurian, bencana alam, seperti banjir likuifaksi dan gempa yang menyebabkan barang jaminan nasabah hilang dan rusak, maka pihak Pegadaian Syariah, maka ganti rugi dapat di lakukan melalui tahapantahapan sebagai berikut:42

1. Pihak pegadaian melaporkan peristiwa tersebut ke kantor polisi

2. Membuat surat pengajuan ke pihak asuransi

3. Pihak asuransi akan turun lapangan untuk memastikan apa yang disampaikan pegadaian sesuai dengan fakta-fakta penyampaian

41 Rizki Oktavian, Pengelola Unit Pegadaian Syariah Pasar Inpres, "Wawancara" Tempat Unit Pegadaian Syariah Pasar Inpres, Senin 27 Mei, detik 16:31.

42 Rezki Octavian, Pengelola Unit Pegadaian Syariah Pasar Inpres, "Wawancara", Tempat Unit Pegadaian Syariah Pasar Inpres,27 Mei 2019. yang tertera di surat pengajuan tersebut

4. Jika fakta tersebut yang disampaikan pegadaian dengan yang terjadi di lapangan benar maka, asuransi akan dibayarkan sesuai dengan barang jaminan

5. Pihak nasabah dan pihak asurasi melakukan komunikasi apakah akan digantikan dengan uang atau dengan barang yang baru.

Dalam hal Pemberian ganti rugi yang diberikan oleh pegadaian syariah Palu Plaza. Rizki Oktavian menyatakan bahwa:

Tinggal komunikasikan dengan nasabahnya lagi kan asuransinya digantikan dengan uang dikomunikasikan dengan nasabahnya apakah mau diganti dengan uang atau dengan barang. ${ }^{43}$

Penggantian biaya ganti rugi kepada nasabah dalam hal ini Rizki Oktavina Menyatakan bahwa:

Kita ada namanya taksiran kita liat taksirannya kalau misalnya minta barang baru maka diliat jumlah taksiranya jadi penggantian barang jaminan dilihat dari taksiranya bukan berdasarkan uang pinjamannya. ${ }^{4}$

Berdasarkan pernyataan tersebut di atas, Pegadaian Syariah Palu Plaza akan memberikan ganti rugi dengan

43 Rizki Oktavian, Pengelola Unit Pegadaian Syariah Pasar Inpres, "Wawancara" Tempat Unit Pegadaian Syariah Pasar Inpres, Senin 27 Mei, detik 19:21.

44 Rizki Oktavian, Pengelola Unit Pegadaian Syariah Pasar Inpres, "Wawancara" Tempat Unit Pegadaian Syariah Pasar Inpres, Senin 27 Mei, detik 19:31. 
memberikan barang yang sesuai dengan jumlah taksiran barang jaminan yang hilang atau rusak, bukan berdasarkan besarnya pinjaman yang telah diterima oleh nasabah. Pada dasarnya, semua barang jaminan yang masuk ke Pegadaian Syariah Palu Plaza terlepas dari kehilangan dan rusak maka pihak pegadaianlah yang pertanggung jawab atas barang jaminan tersebut.

\subsection{Perspektif Ekonom Islam Terhadap} Tanggung Jawab Pegadaian Syariah Islam sangat menekankan perlunya tanggung jawab bagi pengelola atau pihak yang diamanahi untuk menjaga barang jaminan. Berdasarkan hal ini, maka penulis akan menguraikan perspektif ekonomi Islam berkaitan dengan tanggung jawab pihak Pegadaian Syariah Palu Plaza sebagai berikut:

Landasan hukum merupakan pondasi dasar untuk melakukan segala bentuk oprasional dalam suatu lembaga keuangan. Setiap orang yang beriman haruslah patuh kepada Allah dan RasulNya. Aturan-aturan yang dibuat oleh pemerintah dalam suatu lembaga keuangan merupakan kewajiban untuk di patuhi. Allah swt berfirman dalam Q.S An-Nisa (4):59:

"Hai orang-orang yang beriman, taatilah Allah dan taatilah RasulNya, dan ulil amri di antara kamu".

Dalam ayat ini terkandung isyarat bahwa suruhan kepada orangorang yang beriman taat kepada Allah dan taat kepada Rasul dan kepada orang-orang yang memegang, orangorang yang memiliki urusan yakni para penguasa mereka menyuruh menaati
Allah dan Rasul-Nya. ${ }^{45}$ Islam mengatur segala perilaku manusia dalam aspek kehidupannya. Baik di bidang ekonomi sosial maupun bidang politik hal ini juga secara spesifik di anut di dalam lembaga di mana setiap aktivitas mereka. Mereka di atur oleh kitab Undang-Undang Hukum Perdata dan aturan-aturan lainya. Seperti yang terjadi di pegadaian syariah dimana segala kegiatan oprasionalnya di atur kitab Undang-Undang Hukum Perdata (KUHP) pasal 1150, 1154, 1156, 1157, 1244, 1245 dan 1338, sebagaimana yang sudah di ungkapkan sebelumnya pada halaman 59 pada poin A. Bentuk kepatuhan pegadaian syariah Palu Plaza juga termuat dalam salah satu nilai-nilai dasar ekonomi Islam, yaitu nilai kelurusan. Nilai kelurusan diartikan sebagai taat asas atau konsisten menuju tujuan. ${ }^{46}$

Berdasarkan taat hukum atas Undang- Undang Kitab Hukum Perdata (KUHP) tersebut menunjukan bahwa pegadaian syariah komitmen dan konsisten menjalangkan UndangUndang Kitab Hukum Perdata (KUHP) tersebut. Melihat fenomena yang ada di lapangan serta nilai-nilai dasar ekonomi Islam dan berdasarkan hasil wawancara penulis Pegadaian Syariah Palu Plaza menaati Undang-Undang Kitab Hukum Perdata (KUHP) tersebut. sebagai dasar kegiatan oprasionalnya, dalam tinjauan ekonomi Islam yang dilakukan

${ }^{45}$ Al-Imam Jalaluddin Muhammad bin Ahmad bin Muhammad Al-Mahalli Al-Iman Jalaluddin Abdirrahman bin Abu Bakar AsSuyuthi, Tafsir Jalalain, (C,2, Surabaya: PT. Elba Fitrah Mandiri Sejahtera, 2015), 355.

46 Pusat Pengkajian dan Pengembangan Ekonomi Islam, Ekonomi Islam, (Cet , 4, Jakarta: PT Raja Grafindo Persada, 2012), 62.

e-ISSN: 2686-6633 
Pegadaian Syariah Palu Plaza sudah dilakukan sebagaimana mestinya.

Dalam ekonomi Islam pemberian ganti rugi marhun (barang jaminan) hilang dibawa penguasaan murtahin (orang yang menerima barang jaminan) maka murtahin tidak wajib menggantinya, kecuali bila rusak atau hilangnya itu karena kelalaian murtahin atau karena disia-siakan, umpamanya murtahin bermain-main dengan api, lalu terbakar barang gadai itu, atau gudang tidak dikunci, lalu barang-barang itu hilang dicuri orang. Murtahin diwajibkan memelihara sebagaimana layaknya, bila tidak demikian, ketika ada cacat atau kerusakan apalagi hilang, menjadi tanggung jawab murtahi.

Menurut Hanafi, murtahin yang memegang marhun menanggung resiko kerusakan marhun atau kehilangan marhun, bila marhun itu rusak atau hilang, baik karena kelalaian (disiasiakan) maupun tidak. Demikian itu pendapat Ahmad Azhar Basyir.

Perbedaan dua pendapat tersebut ialah menurut Hanafi murtahin harus menanggung resiko kerusakan atau kehilangan mahrum yang dipegangnya, baik mahrun hilang karena disia-siakan maupun dengan sendirinya. Sedangkan menurut syafi'iyah murtahin menanggung resiko kehilangan atau kerusakan marhum bila marhun itu rusak atau disia-siakan murtahin. ${ }^{47}$

Bentuk pertanggung jawaban Pegadaian Syariah Palu Plaza terhadap kerusakan atau hilangnya barang jaminan baik itu disebabkan oleh hilang dan rusak karena kelalaian pihak pegadaian maka Pegadaian Syariah Palu

47 Hendi Suhendi. Fiqih Muamalah, (Ed. 1,8 Jakarta: Rajawali Pers, 2013), 109.
Plaza memberikan ganti rugi sebesar nilai taksiran dari barang jaminan, pegadaian syariah Palu Plaza dapat menggantinya dalam bentuk nominal atau diganti barang yang sama sesuai dengan kesepakatan nasabah dan pihak pegadaian. Pertanggungjawaban ini dapat dipastikan karena barang jaminan nasabah diasuransikan pihak pegadaian.

Pegadaian Syariah Palu Plaza juga memberikan ganti rugi barang jaminan yang disebabkan hilang dan rusak akibat kelalaian pemegang gadai misalnya bermain-main dengan api, lalu terbakar barang gadai itu, atau gudang tidak dikunci, lalu barang-barang itu hilang dicuri orang atau akibat kelalaian pegawai itu sendiri misalnya barang jaminan harus disimpan di dalam berangkas tapi pegawai tersebut lalai menyimpannya lantas barang jaminan tersebut hilang dan rusak. Pihak Pegadaian Syariah Palu Plaza mengansuransikan semua barang jaminan milik nasabah, sehingga Pegadaian Syariah Palu Plaza memiliki tanggung jawab penuh terhadap barang jaminan nasabah. Selain itu, dalam penentuan biaya ganti rugi pegadaian syariah Palu Plaza menentukan berdasarkan nilai taksiran barang jaminan bukan berdasarkan jumlah pinjaman nasabah.

\section{Kesimpulan}

Dari uraian yang penulis kemukakan sebelumnya dapat diambil kesimpulan, bahwa bentuk tanggung jawab pegadaian syariah Palu Plaza terhadap kerusakan atau hilangnya barang jaminan adalah melakukan upaya ansitipasi untuk meminimalisir terjadinya barang jaminan hilang atau 
rusak yaitu adanya dasar oprasional yang melandasi kegiatan pegadaian syariah Palu Plaza dalam hal tanggung jawab atas kerusakan dan kehilangan barang jaminan, kemudian menyediakan sarana dan prasarana untuk menjaga keamanan barang jaminan dan menlakukan pengelolaan barang jaminan yang dilakukan secara berkala. Mengasuransikan barang jaminan dan melakukan ganti rugi apabila terjadi barang jaminan mengalami kehilangan atau kerusakan.

Tanggung jawab yang diberikan pegadaian syariah Palu Plaza dengan melihat fonomena di lapangan, berdasarkan ekonomi Islam, ayat-ayat ekonomi Islam dan berdasarkan hasil wawancara, pegadaian syariah Palu Plaza dalam hal tanggung jawab terhadap barang jaminan yang hilang dan rusak sudah sesuai dengan ekonomi Islam yaitu melakukan upaya ansitipasi untuk meminimalisir terjadinya barang jaminan hilang atau rusak yaitu adanya dasar oprasional yang melandasi kegiatan pegadaian syariah Palu Plaza dalam hal tanggung jawab atas kerusakan dan kehilangan barang jaminan, kemudian menyediakan sarana dan prasarana untuk menjaga keamanan barang jaminan dan melakukan pengelolaan barang jaminan yang dilakukan secara berkala. Mengasuransikan barang jaminan dan melakukan ganti rugi memberikan ganti rugi kepada setiap nasabah yang barang jaminannya hilang dan rusak baik itu hilang dan rusak dengan penentuan biaya ganti rugi ditentukan berdasarkan nilai taksiran barang jaminan bukan berdasarkan jumlah pinjaman nasabah. Sehingga sudah cukup untuk menutup kerugian yang dialami nasabah.

\section{Daftar Pustaka}

Adrian.Hukum Gadai Syariah C. 1; Bandung: PT. Alfabeta, 2011.

Arikunto,Suharsimi. Prosedur Penelitian Suatu Pendekatan Pakte.Cet. XI;Jakarta: PT. Rineka Cipta, 1998.

Al Arif M, Nur Rianto. Lembaga Keuangan Syariah, Bandung: Pustaka Setia, 2012.

Ahmad,Ruslam,

MetodologiPenelitianKualitatif

Cet. I: Yogyakarta: Ar-Ruzz Media, 2014.

Ali, Zainuddin,Hukum Gadai Syariah. C.1; Jakarta: Sinar Grafika, 2008.

Basyir, Azhari Ahmad. Hukum Islam Tentang Riba Utang Piutang Gadai. Bandung: al-Ma'arif, 1983.

Bungin, Burhan.Metode Penelitian Sosial $\mathcal{E}$ Ekonomi, jakarta: Kencana, 2013.

Depertemen Agama RI, Al-Qur,an dan Terjemahnya, Surabaya: Duta Ilmu, 2005.

Depertemen Pendidikan Nasional, Kamus Besar Bahasa Indonesia (Pusat Bahasa). Edisi keempat. Jakarta: Gramedia, 2008.

Djamil,

Faturrahman.PenyelesaianPembiy ayaanBermasalah di Bank,Jakarta: SinarGrafika, 2000.

Djokowidagmdho,dkk.Ilmu Budaya Dasar, Ed. 1, C. 8, Jakarta: Bumi Aksara 2003.

Evi, LutfianaDewi.Pertanggung Jawaban

Terhadap Objek Gadai Oleh

Pegadaian Syariah Ditinjau

Menurut Fiqih Mamalah, 
Universitas Islam Negeri Raden Intan Lampug 2017.

Ghazly, Abdul Rahman. Ghufron Ihsan dan Sapiudin Shidiq. Figh Muamalat. Jakarta: kencana, 2010.

Hadi, Muhammad Shalikul.Pegadaian Syariah, Jakarta: SalembahDiniyah, 2003.

Haerisman,

AlvienSeptian.PegadaianTinjaua $n$ Syariah. PDF File, ( Februari 2016).

20.

www.syehknurjati.ac.id.

(Online, diakses pada tanggal 10 Februari 2019).

Haricahyono, Cheppy. Ilmu Budaya Dasar, Surabaya: Usaha Nasional, 1987.

Haroen,Nasrun.FiqhMuamalah, C. 2, Jakarta: Gaya Media Pertama, 2007.

Idri.Hadis EkonomidalamPerspektif Hadis Nabi,Jakarta: Kencana, 2015

Internasional

Shari'ahResearchAcademyfor Islamic Finance (ISRA). Sistem Keuangan Islam: Prinsip dan Oprasional/ISRA, edisi pertama. Cet.1; Jakarta: Rajawali pers, 2015.

Kahf,Monzer. Ekonomi Islam (AnalitikTerhadapFungsiSistemEk onomi Islam, Yogyakarta: PustakaPelajar, 1995.

Karim A,Adiwarman. Maqashid Bisnis dan Keuangan Islam. Jakarta: Rajawali Pers, 2015.

Kasmir, Bank dan Keuanganlainnya, Ed. Revisi C.17.(Jakarta: PT Raja GrafindoPersada, 2016.

Martono. Bank dan Lembaga Keuangan lain. Yogyakarta: Ekonisa, 2002.
HukumPerdataInternasional dan Nasional, Jakarta: Rajawali Pers, 2013.

Mohammad,

Herry.

44

TeladanKepemimpinan

Muhammad

SAW,Jakarta:

GemaInsani, 2008.

Muhammad. Lembaga Ekonomi Syariah. Jakarta: Graha Ilmu, 2007.

Munir,AbdulPendidikan

Karakter.

Yogyakarta:

PustakaInsanMadani, 2010.

Muslich, Wardi Ahmad. Figh Muamalat. Jakarta: Amzah, 2011.

Mustafa, Al- MaragiAhmad.Terjemah Tafsir Al-Maragi,cet: 1, Semarang: CV. Toha Putra Semarang, 1987.

Musuari,Tanggung Jawab Pegadaian Syariah atas Hilang atau Rusaknya Barang Jaminan dalam Perspetikf Hukum Islam, Universitas Islam Darussalam, Banda Aceh 2016.

Nurdin, N. (2016). The Roles of Information Technology in Islamic Bank Knowledge Management: A study of Two Syariah Banks in Palu. Hunafa: Jurnal Studia Islamika, 13(2), 181217.

https://doi.org/https:/ / doi.org/ 10.24239/jsi.v13i2.444.181-217

Nurdin, N. (2017a). Research in Online Space: The Use of Social Media for Research Setting Jurnal Sistem Informasi (Journal of Information System), 13(1), 67-77.

Nurdin, N. (2017b). To Research Online or Not to Research Online: Using Internet-Based Research in Islamic Studies Context. Indonesian Journal of Islam and Muslim Societies, 7(1), 31-54. 
Ruslan, Rosady.PublicRelations dan Komunikasi. Cet V; Jakarta: PT. Rajawali Pers, 2010.

Rozalinda, Ekonomi Islam Teori dan Aplikasinya pada Aktivitas Ekonomi, Ed, 1, Cet, 3 Jakarta: Rajawali, 2016.

Sadulloh. Pedagogik, Bandung: Alfabeta, 2010, 175.

Sodang, PSiagian. Manajemen Sumber Daya Manusia, Jakarta: Bumi Aksara, 2009.

Subagyo,PJoko. Metode Penelitian dalam Teori dan Praktek. Jakarta: Rimeka Cipta, 1997.

Sudarsono, Heri. Bank dan Lembaga Keuangan Syariah, Edisi 4 Yogyakarta: Ekonisia, 2013.

Sugiyono, Metode penelitian Pendidikan. Cet. XX, Bandung: CV Alvabet, 2014.

Suhendi, Hendi. M.Si. Figh Muamala.Jakarta:Rajawali Pers, 2011.
Sukiman.Seri Pendidikan Orang Tua, Jakarta: KementriaAgama dan Kebudayaan, 2016.

Suryabrata,Suryadi.Metodologi Penelitian, jakarta:Raja Grafindo Persada, 1998.

Sutedi, Andrea. HukumGadai Syariah, Bandung: Alfabeta, 2011.

TaqdirQodratillahdkk, Kamus Bahasa Indonesia untuk Pelajaran/Meity. Jakarta: Badan Pengembangan dan Pembinaan Bahasa, Kementrian Pendidikan dan Kebudayaan, 2011.

Yanggo, TChuzaimahYanggo dan HA, Anshary AZ. Problematika Hukum Islam Kontemporer. Jakarta: Pustaka Firdus, 1997.

Yusuf, Muri.MetodePenelitianKualitatif, Kualitatif\&PenelitianGabungan, Edisi I,Cet.IV: Jakarta: Kencana, 2017 